\title{
Formation of surface protective coatings on arsenopyrite using Al-catecholate complex and its mode of inhibition of arsenopyrite oxidation
}

\author{
Ilhwan Park ${ }^{1, *}$, Carlito Tabelin ${ }^{2}$, Hiroyuki Inano $^{3}$, Kensuke $\mathrm{Seno}^{1}$, Kazuki Higuchi ${ }^{4}$, Mayumi Ito $^{2}$ and Naoki Hiroyoshi ${ }^{2}$ \\ ${ }^{1}$ Division of Sustainable Resources Engineering, Graduate School of Engineering, Hokkaido University, Kita 13, Nishi 8, Kita-ku, \\ Sapporo, 060-8628, Japan \\ ${ }^{2}$ Division of Sustainable Resources Engineering, Faculty of Engineering, Hokkaido University, Kita 13, Nishi 8, Kita-ku, Sapporo, 060- \\ 8628, Japan \\ ${ }^{3}$ Hokkaido Research Organization Industrial Research Institute, Kita 19, Nishi 11, Kita-ku, Sapporo, 060-0819, Japan \\ ${ }^{4}$ Course of Sustainable Resources Engineering, School of Engineering, Hokkaido University, Kita 13, Nishi 8, Kita-ku, Sapporo, 060- \\ 8628 , Japan
}

\begin{abstract}
Arsenopyrite is the most common arsenic-bearing sulfide mineral in nature. It is readily oxidized and releases toxic arsenic (As) into the environment when exposed to atmospheric conditions via anthropogenic activities like mining, mineral processing, extractive metallurgy, and underground space developments. Carrier-microencapsulation (CME) is a technique that uses metal(loid)-organic complexes to selectively form protective coatings on the surfaces of sulfide minerals. In this study, CME using Alcatecholate complexes (i.e., Al-based CME) was investigated to suppress the oxidation of arsenopyrite. Aluminum(III) and catechol form three complex species depending on the $\mathrm{pH}$ and among them, $[\mathrm{Al}(\mathrm{cat})]^{+}$ was the most effective in suppressing arsenopyrite oxidation. Its suppressive effect was improved as $[\mathrm{Al}(\mathrm{cat})]^{+}$concentration increased due most likely to the formation of a more extensive surface protective coating at higher concentrations. Surface characterization of leaching residues using SEM-EDX and XPS indicates that CME-treated arsenopyrite was covered with bayerite $\left(\gamma-\mathrm{Al}(\mathrm{OH})_{3}\right)$. The results of electrochemical studies showed that the surface protective coatings suppressed both anodic and cathodic half-cell reactions of arsenopyrite oxidation.
\end{abstract}

\section{Introduction}

Arsenopyrite (FeAsS) is the most common arsenicbearing sulfide mineral in nature. This mineral is readily oxidized when exposed to atmospheric conditions, leading to the release of arsenic (As) into the environment as explained by the following reaction:

$$
4 \mathrm{FeAsS}+11 \mathrm{O}_{2}+6 \mathrm{H}_{2} \mathrm{O} \rightarrow 4 \mathrm{Fe}^{2+}+4 \mathrm{H}_{3} \mathrm{AsO}_{3}+4 \mathrm{SO}_{4}{ }^{2-}
$$

Arsenic is a strictly regulated substance because of its toxicity. For example, prolonged exposure even to minute amounts of As increases the risks of developing several types of cancers [1]. To mitigate this problem, carrier-microencapsulation (CME), a process that forms a protective coating on the surface of sulfide minerals, was developed by the authors [2-5]. In CME, a redoxsensitive organic compound (e.g., catechol, 1,2dihydroxybenzene, $\mathrm{C}_{6} \mathrm{H}_{4}(\mathrm{OH})_{2}$ ) is used to transform relatively insoluble metal(loid) ions, such as $\mathrm{Ti}^{4+}, \mathrm{Si}^{4+}$, and $\mathrm{Al}^{3+}$, into soluble complexes. Although these complexes are stable in solution, they are oxidatively decomposed on the surfaces of sulfide minerals like pyrite $\left(\mathrm{FeS}_{2}\right)$ and arsenopyrite that dissolve electrochemically. As a consequence of this oxidative decomposition, metal(loid) ions are released and rapidly precipitated near the mineral surface, which form protective metal(loid)-oxyhydroxide coatings.

In our previous work on Al-based CME, arsenopyrite oxidation was successfully suppressed via the formation of Al- and O-containing coatings, but the mechanisms of how the surface protective coatings suppressed arsenopyrite oxidation still remain unclear. Moreover, the detailed characterization of this coating was not conducted.

In this study, the effects of $\mathrm{pH}$ and complex concentration on the suppression of arsenopyrite oxidation by Al-based CME were investigated. Detailed characterization of the coating formed on arsenopyrite was done using scanning electron microscopy with energy dispersive X-ray spectroscopy (SEM-EDX) and X-ray photoelectron spectroscopy (XPS). Finally, electrochemical studies such as cyclic voltammetry (CV) and chronoamperometry using arsenopyrite electrode with and without Al-based CME treatment were carried out to understand the mechanisms involved in the suppression of arsenopyrite oxidation. 


\section{Materials and methods}

\subsection{Arsenopyrite sample characterization}

The arsenopyrite sample used in this study was obtained from Toroku mine, Miyazaki, Japan. It was crushed with a jaw crusher (BB 51, Retsch Inc., Germany), ground in a disk mill (RS 100, Retsch Inc., Germany), and then screened to obtain a size fraction of $100-150 \mu \mathrm{m}$. The sample was analyzed by X-ray powder diffraction (XRD) and confirmed that it was mainly composed of arsenopyrite with pyrite and quartz as minor minerals. The chemical composition of the sample is 32.6, 30.9 and $20.1 \%$ of $\mathrm{Fe}$, As and $\mathrm{S}$, respectively, and these values are equivalent to ca. $67 \%$ of arsenopyrite, $13 \%$ of pyrite and $15 \%$ of quartz.

\subsection{Characterization of Al-catecholate complexes}

Three types of Al-catechol solutions were prepared using $\mathrm{AlCl}_{3} \cdot 6 \mathrm{H}_{2} \mathrm{O}$ and pyrocatechol (Wako Pure Chemical Industries, Ltd., Japan): (1) $2 \mathrm{mM}$ of $\mathrm{Al}^{3+}$ and $2 \mathrm{mM}$ of catecholate at $\mathrm{pH} 5$, (2) $2 \mathrm{mM}$ of $\mathrm{Al}^{3+}$ and $4 \mathrm{mM}$ of catechol at $\mathrm{pH} \mathrm{7}$, and (3) $2 \mathrm{mM}$ of $\mathrm{Al}^{3+}$ and $6 \mathrm{mM}$ of catechol at $\mathrm{pH} 10$, all of which contain $0.1 \mathrm{M} \mathrm{NaCl}$ to maintain a constant ionic strength. These solutions were immediately analyzed by UV-vis light spectrophotometer (V-630, Jasco Analytical Instruments, Japan).

\subsection{Batch leaching experiments}

Before the leaching experiments, the arsenopyrite sample was washed using the method developed by McKibben et al. [6] to remove any oxidized layer formed during sample preparation and storage. One gram of washed sample and $10 \mathrm{ml}$ of Al-catechol solutions were put into a 50-ml Erlenmeyer flask and shaken in a constant temperature water bath $\left(25^{\circ} \mathrm{C}\right)$ at $120 \mathrm{~min}^{-1}$. Leaching

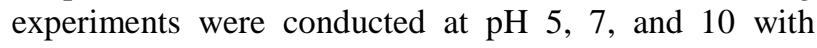
various complex concentrations $(0-15 \mathrm{mM})$. After 7 days, the $\mathrm{pH}$ and $\mathrm{Eh}$ of suspensions were measured and then filtered through $0.2 \mu \mathrm{m}$ syringe-driven membrane filters. The filtrate was immediately analyzed by inductively coupled plasma atomic emission spectrometer (ICP-AES, ICPE-9820, Shimadzu Corporation, Japan; margin of error $= \pm 2 \%$ ) while the residue was thoroughly washed with deionized (DI) water, dried in a vacuum oven and analyzed by SEMEDX (SSX-550, Shimadzu Corporation, Japan) and XPS (Axis-His, Shimadzu/Kratos Corporation, Japan). The XPSPEAK4.1 software was used to deconvolute and fit the XPS spectra.

\subsection{Electrochemical studies}

Electrochemical experiments were carried out using SI 1280 B electrochemical measurement unit (Solartron Instruments, UK) with a conventional three-electrode system. An arsenopyrite electrode, a platinum (Pt) electrode, and an $\mathrm{Ag} / \mathrm{AgCl}$ electrode filled with saturated $\mathrm{KCl}$ were used as working, counter, and reference electrodes, respectively. Preparation of the arsenopyrite electrode was described in our previous work [5].

The arsenopyrite electrode was polished with a series of silicon carbide papers (\#600, \#1000, and \#1500) and alumina $\left(\mathrm{Al}_{2} \mathrm{O}_{3}\right)$ pastes $(5$ and $1 \mu \mathrm{m})$. After this, the polished electrode was ultrasonically cleaned for $5 \mathrm{~min}$ to remove residual $\mathrm{Al}_{2} \mathrm{O}_{3}$ particles and then washed with DI water.

Prior to each measurements, the arsenopyrite electrode was treated in either $45 \mathrm{mM} \mathrm{NaCl}$ solution (i.e., control) or $15 \mathrm{mM}[\mathrm{Al}(\mathrm{cat})]^{+}$solution (i.e., CME-treated) both of which have $\mathrm{pH}$ of 5.0. After treating for 3 days, the electrode was thoroughly washed with DI water and then used for the electrochemical experiments.

For the $\mathrm{CV}$ measurements, the three electrodes were immersed in $0.1 \mathrm{M} \mathrm{Na} \mathrm{SO}_{4}$ supporting electrolyte solution, which was equilibrated at $25{ }^{\circ} \mathrm{C}$ and deoxygenated by $\mathrm{N}_{2}$ purging for $30 \mathrm{~min}$ beforehand. All measurements started after equilibration at the open circuit potential (OCP) and the sweep direction was towards increasingly positive potentials first. The voltammograms were recorded between 0.0 and $+1.0 \mathrm{~V}$ vs. SHE at a scan rate of $5 \mathrm{mV} / \mathrm{s}$.

Chronoamperometry was carried out using a setup similar to the CV measurements but with stirring at 250 $\mathrm{rpm}$. The working electrode was first equilibrated at the OCP and then polarized at $0.0 \mathrm{~V}$ for cathodic polarization (without $\mathrm{N}_{2}$ purging) and at $+0.8 \mathrm{~V}$ for anodic polarization (with $\mathrm{N}_{2}$ purging). These potentials were selected based on the previous studies $[7,8]$ : arsenopyrite was irreversibly oxidized at $+0.8 \mathrm{~V}$ while its reductive dissociation was negligible at $0.0 \mathrm{~V}$.

\section{Results and discussion}

\subsection{Effects of the complex species on the suppression of arsenopyrite oxidation}

$\mathrm{Al}^{3+}$ and catechol (cat) are known to form three complex species depending on the $\mathrm{pH}[\mathbf{5}, \mathbf{9}]$. As shown in Fig. 1(a), $[\mathrm{Al}(\mathrm{cat})]^{+},\left[\mathrm{Al}(\mathrm{cat})_{2}\right]^{-}$, and $\left[\mathrm{Al}(\mathrm{cat})_{3}\right]^{3-}$ are dominant

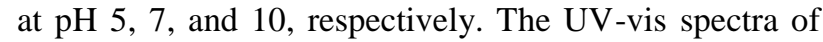
Al-catechol solution at $\mathrm{pH} \mathrm{5,7,} \mathrm{and} 10$ show three distinct peaks (Fig. 1(b)), which supports the formation of three Al-catecholate complexes.

Based on these results, the three Al-catecholate complexes were prepared at $\mathrm{pH} 5,7$, and 10 , and used for the leaching experiments to investigate how they affect arsenopyrite oxidation. As illustrated in Fig. 1(c), the concentrations of dissolved $\mathrm{Fe}$, As, and $\mathrm{S}$ (i.e., the oxidation products of arsenopyrite) were the lowest at $\mathrm{pH}$ 5 , indicating that among the three complexes, $[\mathrm{Al}(\mathrm{cat})]^{+}$ was the most effective. This result is consistent with lower dissolved $\mathrm{Al}$ concentration, implying that the suppression of arsenopyrite oxidation was related to the formation of a coating (Fig. 1(d)). Moreover, $[\mathrm{Al}(\mathrm{cat})]^{+}$ likely formed more coating and suppressed arsenopyrite oxidation more effectively than $\left[\mathrm{Al}(\mathrm{cat})_{2}\right]^{-}$and $\left[\mathrm{Al}(\mathrm{cat})_{3}\right]^{3-}$ based on the differences in the amounts of dissolved $\mathrm{Al}$ and oxidation products. 
(a)

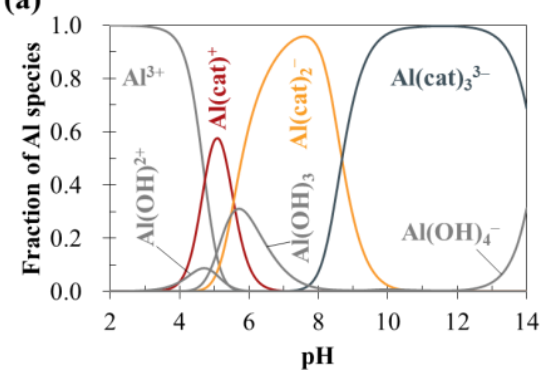

(b)

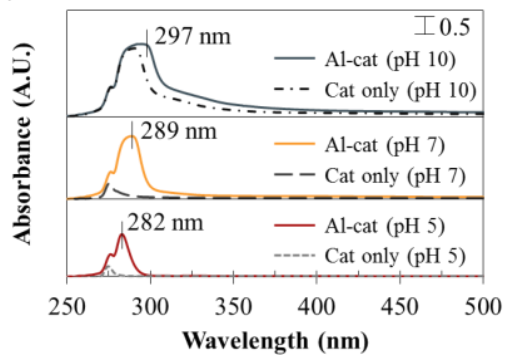

(c)

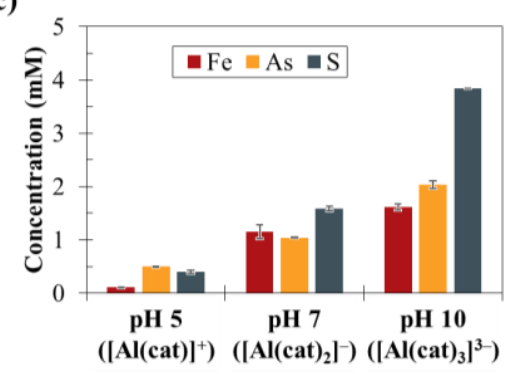

(d)

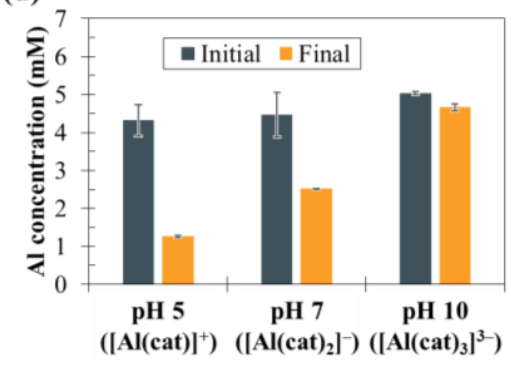

Fig. 1. Effects of Al-catecholate complexes on the arsenopyrite oxidation: (a) The speciation diagram of $\mathrm{Al}^{3+}$-catechol- $\mathrm{H}_{2} \mathrm{O}$ system, and (b) UV-vis spectra of Al-catechol and catechol solutions at $\mathrm{pH} 5,7$, and 10, the changes in (c) dissolved Fe, As, and S concentrations, and (d) initial and final concentrations of dissolved Al. This figure is modified with the permission from Chemosphere [5].

\subsection{Effects of the concentration of [Al(cat)] ${ }^{+}$on the suppression of arsenopyrite oxidation}

More extensive suppression of the oxidation of arsenopyrite was observed with increasing $[\mathrm{Al}(\mathrm{cat})]^{+}$ concentration (Fig. 2(a)). In the absence of this complex, arsenopyrite was substantially oxidized and released ca. $3.3 \mathrm{mM}$ of $\mathrm{Fe}, 6.1 \mathrm{mM}$ of As, and $9.8 \mathrm{mM}$ of $\mathrm{S}$ while only $0.13 \mathrm{mM}$ of $\mathrm{Fe}, 0.69 \mathrm{mM}$ of As, and $0.24 \mathrm{mM}$ of S were released in $15 \mathrm{mM}$ of [Al(cat)] ${ }^{+}$solution. Moreover, large amount of dissolved $\mathrm{Al}$ was precipitated as the $[\mathrm{Al}(\mathrm{cat})]^{+}$concentration increased, implying that the formation of coating was probably enhanced and became more extensive at higher $[\mathrm{Al}(\mathrm{cat})]^{+}$concentration (Fig. 2(b)).

(a)

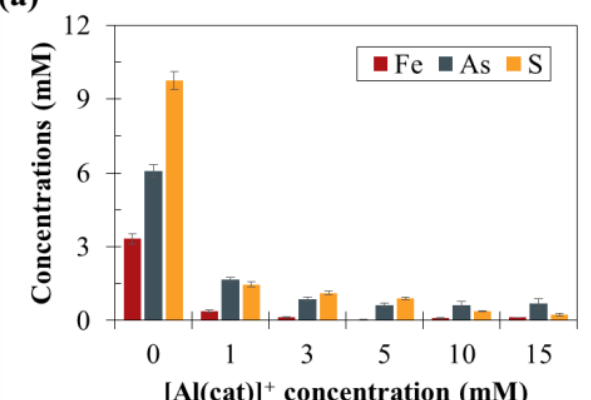

(b)

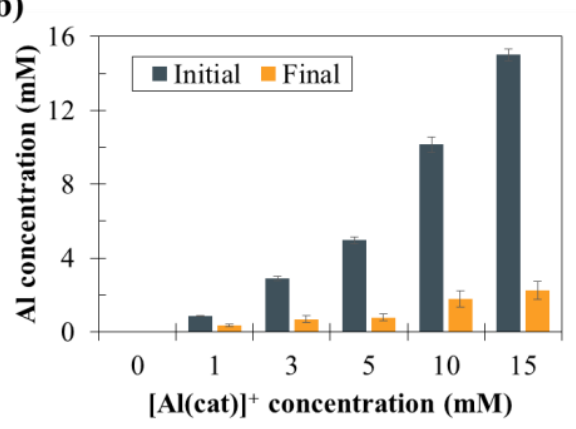

Fig. 2. Effects of $[\mathrm{Al}(\mathrm{cat})]^{+}$concentrations on arsenopyrite oxidation: changes in (a) dissolved $\mathrm{Fe}$, As, and S concentrations, and (b) initial and final concentrations of dissolved Al. This figure is modified with the permission from Chemosphere [5].

\subsection{Surface characterization of CME-treated arsenopyrite}

The arsenopyrite sample treated with $15 \mathrm{mM}[\mathrm{Al}(\mathrm{cat})]^{+}$ for 7 days was analyzed by SEM-EDX (Fig. 3). The results show signals of $\mathrm{Al}$ and $\mathrm{O}$ on the surface of arsenopyrite, indicating that an $\mathrm{Al}-$ and O-bearing coating was formed during CME treatment. To characterize this coating in detail, the samples treated with control and $15 \mathrm{mM}[\mathrm{Al}(\mathrm{cat})]^{+}$were analyzed by XPS. As shown in Fig. 4(a), XPS spectrum (A1 2p) of the control has no distinct peak while the spectrum of CMEtreated arsenopyrite shows a broad peak centered at ca. $75 \mathrm{eV}$. Deconvolution of this peak using a GaussianLorentzian function indicates that it has two $\mathrm{Al} 2 \mathrm{p}$ transitions at 74.6 and $75.3 \mathrm{eV}$, respectively. According to Kloprogge et al. [10], the former is associated with bayerite $\left(\gamma-\mathrm{Al}(\mathrm{OH})_{3}\right)$ and the latter is most likely its amorphous phase.

XPS spectrum (O 1s) of CME-treated arsenopyrite (Fig. 4(b)) shows two $\mathrm{O}$ 1s transitions at ca. 532.1 and $533.1 \mathrm{eV}$, respectively, most likely attributed to the hydroxyl groups in the crystal structure of bayerite (i.e., $\mathrm{Al}-\mathrm{O}-\mathrm{H})$ and absorbed water on the surface $(\mathrm{H}-\mathrm{O}-\mathrm{H})$ [10]. In contrast, XPS spectrum (O 1s) of the control shows an additional peak of $\mathrm{O}(-\mathrm{II})$, indicating that arsenopyrite oxidation has proceeded to much greater extent compared with CME-treated arsenopyrite [11]. 


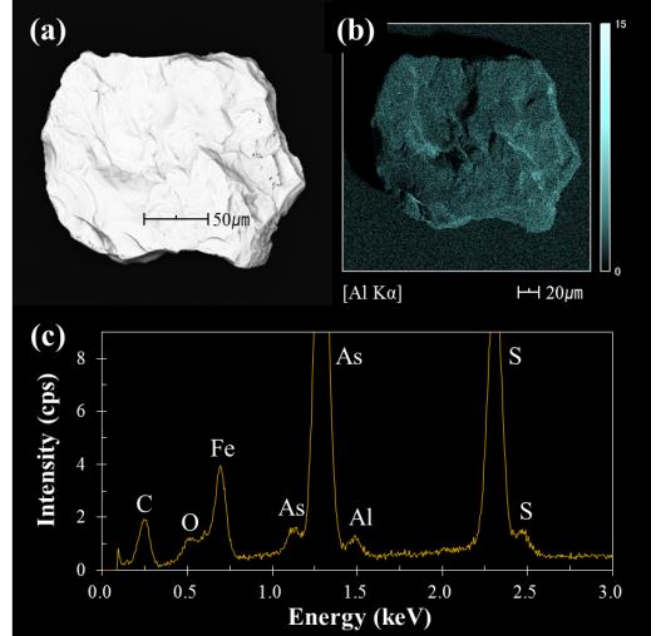

Fig. 3. SEM-EDX analysis of arsenopyrite treated with $15 \mathrm{mM}$ [Al(cat) $]^{+}$for 7 days: (a) SEM photomicrograph, (b) elemental map of $\mathrm{Al}$, and (c) energy dispersive X-ray spectrum of the scanned area. This figure is modified with the permission from Chemosphere [5].
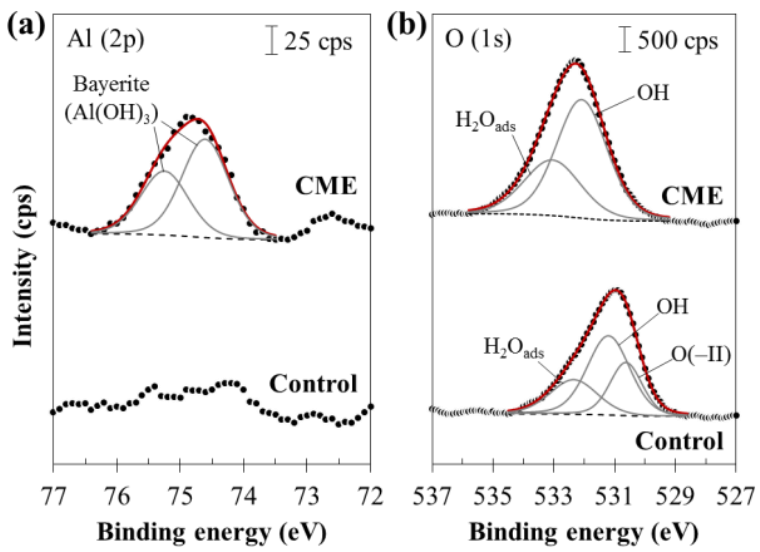

Fig. 4. XPS spectra of arsenopyrite treated with $45 \mathrm{mM} \mathrm{NaCl}$ (control) and $15 \mathrm{mM}[\mathrm{Al}(\mathrm{cat})]^{+}$(CME) for (a) $\mathrm{Al} 2 \mathrm{p}$ and (b) $\mathrm{O}$ $1 \mathrm{~s}$.

\subsection{Mechanisms of suppression of Al-based CME}

The cyclic voltammogram of the control (treated in $\mathrm{NaCl}$ solution) shows several anodic and cathodic peaks (Fig. 5). During the anodic sweep, high anodic current was recorded above $0.7 \mathrm{~V}$ because of several interrelated anodic reactions of arsenopyrite and its oxidation products as explained by the following reactions $[7,8]$ :

$$
\begin{gathered}
\mathrm{FeAsS} \rightarrow \mathrm{Fe}^{2+}+1 / 2 \mathrm{As}_{2} \mathrm{~S}_{2}+2 \mathrm{e}^{-} \\
\mathrm{As}_{2} \mathrm{~S}_{2}+6 \mathrm{H}_{2} \mathrm{O} \rightarrow 2 \mathrm{H}_{3} \mathrm{AsO}_{3}+2 \mathrm{~S}^{0}+6 \mathrm{H}^{+}+6 \mathrm{e}^{-} \\
\mathrm{Fe}^{2+}+2 \mathrm{H}_{2} \mathrm{O} \rightarrow \mathrm{FeOOH}+3 \mathrm{H}^{+}+\mathrm{e}^{-} \\
\mathrm{H}_{3} \mathrm{AsO}_{3}+\mathrm{H}_{2} \mathrm{O} \rightarrow \mathrm{H}_{2} \mathrm{AsO}_{4}^{-}+3 \mathrm{H}^{+}+2 \mathrm{e}^{-} \\
\mathrm{S}^{0}+4 \mathrm{H}_{2} \mathrm{O} \rightarrow \mathrm{SO}_{4}{ }^{2-}+8 \mathrm{H}^{+}+6 \mathrm{e}^{-}
\end{gathered}
$$

During the cathodic sweep, three distinct cathodic peaks were observed (i.e., $\mathrm{C}_{1}, \mathrm{C}_{2}$, and $\mathrm{C}_{3}$ ), which are most likely the reduction of oxidation products (Eqs. 79), generated from the previous anodic sweep $[7,8]$.

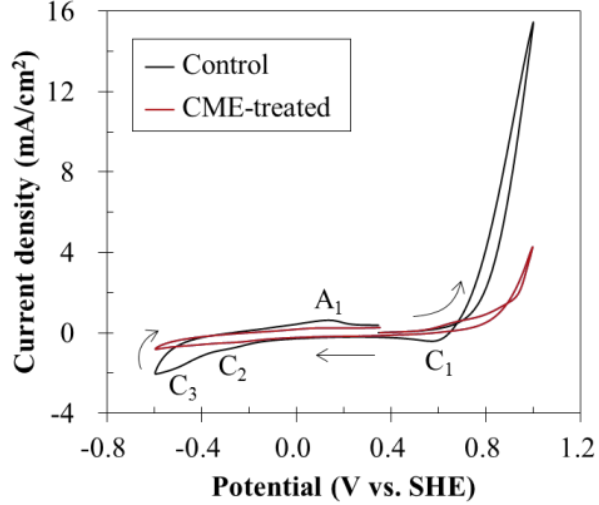

Fig. 5. Cyclic voltammograms of arsenopyrite after treatment with $45 \mathrm{mM} \mathrm{NaCl}$ (control) and $15 \mathrm{mM}[\mathrm{Al} \text { (cat) }]^{+}$(CMEtreated). Note that the arrows denote the sweep direction.

$$
\begin{gathered}
\mathrm{FeOOH}+3 \mathrm{H}^{+}+\mathrm{e}^{-} \rightarrow \mathrm{Fe}^{2+}+2 \mathrm{H}_{2} \mathrm{O} \\
\mathrm{H}_{2} \mathrm{AsO}_{4}^{-}+3 \mathrm{H}^{+}+2 \mathrm{e}^{-} \rightarrow \mathrm{H}_{3} \mathrm{AsO}_{3}+\mathrm{H}_{2} \mathrm{O} \\
2 \mathrm{H}_{3} \mathrm{AsO}_{3}+2 \mathrm{~S}^{0}+6 \mathrm{H}^{+}+6 \mathrm{e}^{-} \rightarrow \mathrm{As}_{2} \mathrm{~S}_{2}+6 \mathrm{H}_{2} \mathrm{O}
\end{gathered}
$$

At the minimum potential (i.e., $0 \mathrm{~V}$ vs. SHE), the sweep direction was reversed to the anodic direction, and an additional anodic peak (i.e., $\mathrm{A}_{1}$ ) appeared at ca. 0.15 $\mathrm{V}$, implying the oxidation of $\mathrm{As}_{2} \mathrm{~S}_{2}$ as illustrated in the reaction (Eq. 3).

In contrast, the cyclic voltammogram of CME-treated arsenopyrite did not show apparent anodic and cathodic peaks. The decrease in anodic current density above 0.7 $\mathrm{V}$ and the disappearance of several peaks could be attributed to the formation of surface protective coatings.

To clarify how the coating suppressed arsenopyrite oxidation, chronoamperometry was conducted because with this technique, it is possible to decouple the anodic and cathodic half-cell reactions of arsenopyrite oxidation (Eqs. 10 and 11).

$$
\begin{aligned}
& \mathrm{FeAsS}+7 \mathrm{H}_{2} \mathrm{O} \rightarrow \mathrm{Fe}^{2+}+\mathrm{H}_{3} \mathrm{AsO}_{3}+\mathrm{SO}_{4}^{2-}+ \\
& 11 \mathrm{H}^{+}+11 \mathrm{e}^{-} \\
& 4 \mathrm{H}^{+}+\mathrm{O}_{2}+4 \mathrm{e}^{-} \rightarrow 2 \mathrm{H}_{2} \mathrm{O}
\end{aligned}
$$

As shown in Fig. 6(a), the current density during anodic polarization was lower when arsenopyrite was treated by Al-based CME, which means that the coating formed on arsenopyrite acts as a barrier against water and thus suppresses the anodic half-cell reaction of arsenopyrite oxidation (Eq. 10).

Similarly, the cathodic polarization results $($ Fig. $6(\mathbf{b}))$ show that the current density of CME-treated arsenopyrite was less negative, indicating that $\mathrm{O}_{2}$ reduction (Eq. 11) was suppressed due most likely to the insulating nature of $\mathrm{Al}$-oxyhydroxide coating. Based on these results, the coating formed by Al-based CME suppressed both the anodic and cathodic half-cell reactions of arsenopyrite oxidation. 
(a)

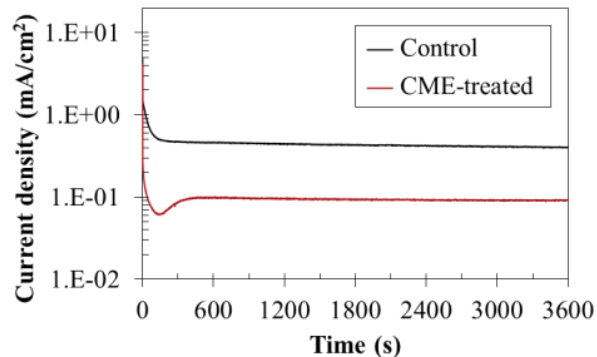

(b)

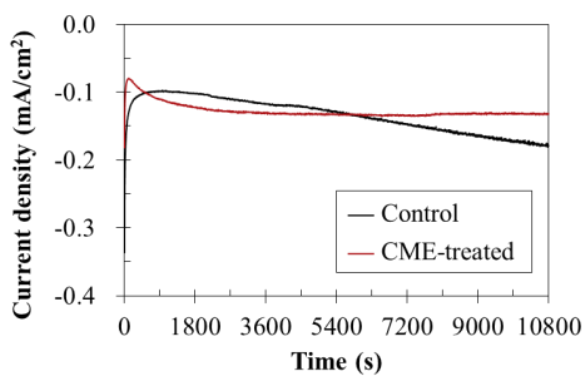

Fig. 6. Chronoamperometric response of arsenopyrite pretreated with $45 \mathrm{mM} \mathrm{NaCl}$ (control) and $15 \mathrm{mM} \mathrm{[Al(cat)]^{+ }}$ (CME-treated): (a) anodic polarization at $+0.7 \mathrm{~V}$ vs. SHE, and (b) cathodic polarization at $0.0 \mathrm{~V}$ vs. SHE.

\section{Conclusion}

This study investigated the suppression of arsenopyrite oxidation by Al-based CME and clarified the mechanisms of how the technique inhibited this process. $[\mathrm{Al}(\mathrm{cat})]^{+}$suppressed the oxidation of arsenopyrite and its suppressive effects improved with increasing $[\mathrm{Al}(\mathrm{cat})]^{+}$concentration. After $\mathrm{CME}$ treatment, arsenopyrite was covered with bayerite $\left(\gamma-\mathrm{Al}(\mathrm{OH})_{3}\right)$ that suppressed both anodic and cathodic half-cell reactions of arsenopyrite oxidation by blocking the contact of $\mathrm{O}_{2}$ and water to arsenopyrite surface.

This study was financially supported by the Japan Society for the Promotion of Science (JSPS) grant-in-aid for Scientific research (KAKENHI) (Grant numbers: JP17H03503 and JP17K12831).

\section{References}

[1] Tabelin, C.B., Igarashi, T., Villacorte-Tabelin, M., Park, I., Opiso, E.M., Ito, M. and Hiroyoshi, N. Arsenic, selenium, boron, lead, cadmium, copper, and zinc in naturally contaminated rocks: A review of their sources, modes of enrichment, mechanisms of release, and mitigation strategies, Science of the Total Environment 645, 2018, 1522-1553.

[2] Satur, J., Hiroyoshi, N., Tsunekawa, M., Ito, M. and Okamoto, H. Carrier-microencapsulation for preventing pyrite oxidation, International Journal of Mineral Processing 83(3-4), 2007, 116-124.

[3] Jha, R.K.T., Satur, J., Hiroyoshi, N., Ito, M. and Tsunekawa, M. Carrier-microencapsulation using Sicatechol complex for suppressing pyrite floatability, Minerals Engineering 21(12-14), 2008, 889-893.

[4] Park, I., Tabelin, C.B., Magaribuchi, K., Seno, K., Ito, M. and Hiroyoshi, N. Suppression of the release of arsenic from arsenopyrite by carriermicroencapsulation using Ti-catechol complex, Journal of Hazardous Materials 344, 2018, 322-332.

[5] Park, I., Tabelin, C.B., Seno, K., Jeon, S., Ito, M. and Hiroyoshi, N. Simultaneous suppression of acid mine drainage formation and arsenic release by Carriermicroencapsulation using aluminum-catecholate complexes, Chemosphere 205, 2018, 414-425.

[6] McKibben, M.A., Tallant, B.A. and de Angel, J.K. Kinetics of inorganic arsenopyrite oxidation in acidic aqueous solutions, Applied Geochemistry 23, 2008, 121-135.

[7] Almedia, C.M.V.B. and Giannetti, B.F. Electrochemical study of arsenopyrite weathering, Physical Chemistry Chemical Physics 5, 2003, 604610.

[8] Urbano, G., Reyes, V.E., Veloz, M.A., González, I. Cruz, J. Pyrite-arsenopyrite galvanic interaction and electrochemical reactivity, The Journal of Physical Chemistry C 112, 2008, 10453-10461.

[9] Nurchi, V.M., Pivetta, T., Lachowicz, J.I. and Crisponi, G. Effect of substituents on complex stability aimed at designing new iron(III) and aluminum(III) chelators, Journal of Inorganic Biochemistry 103, 2009, 227-236.

[10] Kloprogge, J.T., Duong, L.V., Wood, B.J. and Frost, R. XPS study of the major minerals in bauxite: Gibbsite, bayerite and (pseudo-)boehmite, Journal of Colloid and Interface Science 296(2), 2006, 572-576.

[11] Nesbitt, H.W., Muir, I.J. and Pratt, A.R. Oxidation of arsenopyrite by air and air-saturated, distilled water, and implications for mechanism of oxidation, Geochimica et Cosmochimica Acta 59(9), 1995, 1773-1786. 